\title{
環境水中におけるクロムの分布と挙動 一揖保川および播磨灘について一
}

\author{
（1991 年 2 月 25 日受理）
}

尾 崎 富生*・吉村哲彦・奥野年秀

\section{1 緒訔}

クロムは環境水中で三洒と六洒の酸化状態で存在していること が占くから知られている ${ }^{1) \sim 4 。}$ 環境水中では $\mathrm{Cr}(\mathrm{III})$ はイオン状 態で存在していることはまれであり, 種々の無機および有機の配 位子と結合している。強い酸化力を持つ $\mathrm{Cr}(\mathrm{V})$ の毒性について はよく知られている ${ }^{1 / 2)}$ 。一方， $\operatorname{Cr}($ III) の琴作用は一般的に生体 に対して低いといわれている(12)が， $\mathrm{Cr}$ (III) の有機錯体の生体に 対する影響も最近指摘されている5)。したがって, 環境中に存在 するクロムの生体に対する影響を理解する上では, 環境水中の有 機態 $\operatorname{Cr}($ III ) を含むクロムの存在状態を明らかにすることが必要 である。

環境水中のクロムの分析は, 共沈一原子吸光分析法 ${ }^{6)}$, 共沈-吸 光分析法 ${ }^{778)}$, 共沈一蛍光 $\mathrm{X}$ 線分析法 ${ }^{91}$, 溶媒抽出一原子吸光法 ${ }^{10111)}$, 溶媒抽出ーガスクロマトグラフ法 ${ }^{12) 13)}$, 溶媒抽出一同位体希瀵質量 分析法 ${ }^{14)}$, 溶媒抽出一吸光分析法 ${ }^{15)}$, 吸光分析法 ${ }^{16)}$ などにり行わ れている。しかし，これらの報告は， $\mathrm{Cr}(\mathrm{V})$ および $\mathrm{Cr}$ (III) に関

兵庫県立公害研究所， 654 神戸市須磨区行平町

1) National Research Council 編, 木村正已, 小野 哲, 和田 攻訳, “環境污染物質の生体への影響 2 ク口ム・ バナジゥム”, 東京化学同人(1977).

2）吉川博, “クロム化合物一クロムの環境污染と生体影響”, 日本公采衛生協会(1975).

3）大崎 進, 大崎知恵, 高島良正, 日化, 1980, 1800.

4) R. E. Cranston, J. W. Murray, Limnol. Oceanogr., 25, 1104(1980).

5) J. R. Hatherill, Drug Chem. Toxicol., 4, 185(1981).

6) K. Fujiwara, S. Toda, K. Fuwa, Bull. Chem. Soc. Jpn., 54, 3209(1981).

7) H. Yamazaki, Anal. Chim. Acta, 113, 131(1980).

8）石野二三枝，宗森 信，日化，1984，1404.

9) A.J.Pik, J. M. Eckert, K. L. Williams, Anal. Chim. Acta, 124, 351(1981).

10）日色和夫, 応和 尚, M. Takaoka, 田中 孝, 川原昭宣, 分析化学, 25, 122(1976).

11) G. J.de Jong, U.A.Th. Brinkman, Anal. Chim. Acta, 98, 243(1978).

12) R. J. Lovett, G.F. Lee, Environ. Sci. Technol., 10, 67(1976).

13）田中英樹, 中野貴彦, 金沢良昭, 分析化学, 32, 740(1983).

14）大崎 進, 大崎知恵, 柴田誠一, 高島良正, 分析化学, 25, 358(1976).

15) 藤井和子, 楠山 尚, 小西一生, 分析化学, 24, 332(1975).

16) G. Fung, C. Miao, Analyst, 110, 65(1985).
するものであり，有機態 $\mathrm{Cr}$ (III) に関する報告は少ない。Naka yama らは, 海水中の溶存ク口ムを水酸化鉄 (III) および水酸化ビ スマス共沈法により $\mathrm{Cr}(\mathrm{V})$, 無機態 $\mathrm{Cr}($ III) および有機態 $\mathrm{Cr}$ （III）に分別定量した ${ }^{17)}$ 。また, Obiols らは,リン酸鉛および硫酸 鉛を用いる共沈法により，淡水中のクロムを䀣濁物質に含まれる クロム, 溶存 $\operatorname{Cr}(\mathrm{V})$, 無機態 $\operatorname{Cr}(\mathrm{III})$ および錯体 $\mathrm{Cr}$ (III) に分別 定量した ${ }^{18)}$ 。Osaki らは, 水酸化鉄(III) 共沈法では, $\mathrm{Cr}$ (III)EDTA 錯体を除く有機態 $\mathrm{Cr}$ (III) が共沈することを指摘してい る19)。

著者らは, Nakayama らの分別定量法を一部改良し, 河川水お よび海水に適用した ${ }^{20121)}$ 。兵庫県には数多くの皮革工場が立地し ている。皮革工場の排水中には多量のクロムおょび有機物が含 まれている22)。皮革排水の流入している河川水中には有機態 $\mathrm{C}_{\mathbf{r}}$ (III) $(0.3 \sim 4.5 \mu \mathrm{g} / l)$ が存在していることが明らかになってい $3^{20)}$ 。

環境水中のクロムは, 河川の上流から下流そして海域へと移行 する中で, 水質の変化と共に濃度や状態が变化していくと考えら れる。特に, 河川水と海水が混合する河口域では, イオン強度, 酸化還元電位等が急激に変化し，クロムは複雑な反応を受け变化 することが予想される。このような環境中におけるク口ムの分布 と举動を研究する上では, ク口ムと有機物を多量に含む皮革排水 の影響を受けている河川は有用な研究対象である。本研究では, 皮革排水の影響を受けている兵庫県西部の揖保川および揖保川が 流入している播磨灘におけるクロムの存在状態, および河川から 海域へのクロムの存在状態の变化を追跡した。

\section{2 実験}

\section{1 試薬および装置}

$\mathrm{Cr}(\mathrm{V})$ 標準溶液, 水酸化鉄 $(\mathrm{III})$ ，水酸化ビスマスおよびペル オキソ二硫酸アンモニウムは既報の調製法により調製した ${ }^{20)}$ 。 の他の試薬は有害金属測定用などのできるだけ高純度の試薬を用

17) E. Nakayama, T.Kuwamoto, H. Tokoro, T. Fujinaga, Anal. Chim. Acta, 131, 247(1981).

18) J. Obiols, R. Devesa, J. G. Berro, J.Serra, Intern. J. Environ. Anal. Chem., 30, 197(1987).

19) S. Osaki, T. Osaki, N. Hirashima, I. Takashima, Talanta, 30, 523(1983).

20）尾崎富生，吉村哲彦，新谷幸三，水質污濁研究，8，184 (1985).

21）尾崎富生，吉村哲彦，奥野年秀，兵庫県公害研究所報告， 20, 143(1988).

22）杉田正見，産業公㫪，20，924(1984). 


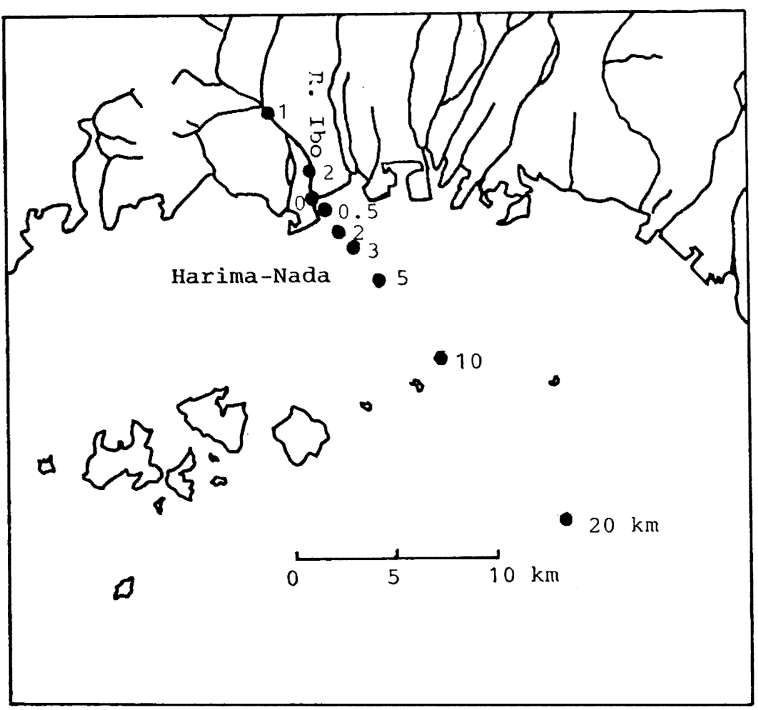

Fig. 1 Sampling locations at the river (Ibo River) and sea site (Harima Nada)

Table 1 Analytical results of particulate chromium in river and sea waters

$$
\operatorname{Cr}(\mathrm{P})^{a)} \operatorname{Cr}(\mathrm{T})^{a)} \quad \operatorname{Cr}(\mathrm{P}) / \mathrm{Cr}(\mathrm{T})
$$

Sampling stations $(\mu \mathrm{g} / l) \quad(\mu \mathrm{g} / l)$

$\begin{array}{lccc}\text { R. Ibo } 1^{b)} & 18.9 & 25.1 & 0.75 \\ 2^{b)} & 4.0 & 7.4 & 0.54 \\ \text { Estuary } & 4.6 & 8.6 & 0.53 \\ \begin{array}{l}\text { 0.5 km offing from } \\ \text { the estuary }\end{array} & 0.43 & 0.96 & 0.45 \\ 2 \mathrm{~km} & 0.20 & 0.57 & 0.35 \\ 3 \mathrm{~km} & 0.07 & 0.37 & 0.19 \\ 5 \mathrm{~km} & 0.02 & 0.22 & 0.09 \\ 10 \mathrm{~km} & 0.01 & 0.14 & 0.07 \\ 20 \mathrm{~km} & 0.01 & 0.14 & 0.07\end{array}$

a) $\mathrm{Cr}(\mathrm{P})$, particulate concentration of $\mathrm{Cr} ; \mathrm{Cr}(\mathrm{T})$, total concentration of $\mathrm{Cr}$ in dissolved and particulate states.

b) The site at the same river is numbered from up to down stream.
いた。

装置は, 日立 180-30 形原子吸光 - 炎光分光光度計, 日立 180-80 形偏光ゼーマン原子吸光光度計拈よび堀場 F-8 AT 形 $\mathrm{pH}$ メーターを用いた。

\section{2 試料の調製およびクロムの分別定量法}

河川扰よび海域の採水地点を図 1 に示す。揖保川および揖保川 の河口から沖合い $20 \mathrm{~km}$ までの播磨灘で表層水を採取した。試 水は, ニュクリポアーフィルター $(0.4 \mu \mathrm{m})$ で, 沪過し, 沪液と 懸濁物質に分離した。

㗭濁物質に含まれるクロムの分析は既法の通りに行った ${ }^{23)}$ 。

河川水および海水中の溶存クロムは既報の通り, $\mathrm{Cr}(\mathrm{V})$, 無機 態 $\operatorname{Cr}(\mathrm{III})$ および有機態 $\mathrm{Cr}(\mathrm{III})$ に分別定量した ${ }^{20121)}$ 。本分別定 量法の概要を以下に示す。（1）試水中の無機態 $\mathrm{Cr}(\mathrm{III})$ を水酸化 鉄（III）共沈法により分別定量する。（2）水酸化ビスマス沈殿を 試水に加えることにより，無機態 $\mathrm{Cr}(\mathrm{III})$ と $\mathrm{Cr}(\mathrm{V})$ は同時に共 沈するので, 得られた沈殿から [無機態 $\mathrm{Cr}(\mathrm{III})+\mathrm{Cr}(\mathrm{V})]$ の濃 度を求める。（3）試水中の有機物をペルオキソ二硫酸塩で分解 し，水酸化ビスマス共沈法で溶存全クロムを定量する。これらの 定量值より， $\operatorname{Cr}(\mathrm{VI})$ ，無機態 $\operatorname{Cr}($ III $)$ および有機態 $\operatorname{Cr}($ III $)$ を算 出する。

上記のクロムの濃度はフレーム原子吸光法または，黒鉛炉原子 吸光法で定量した。

\section{3 結果 と考察}

\section{1 揖保川および播磨灘における懸濁物質に含まれるクロム}

揖保川特よび播磨灘における奬濁物質に含まれるクロムの分析 結果を表 1 に示す。表 1 に示したように懸濁物質に含まれるクロ ム $(\operatorname{Cr}(\mathrm{P}))$ は，揖保川の上流から河口にいくにしたがって徐々 に減少し，河口から沖合い $0.5 \mathrm{~km}$ の間で急激に減少した。 0.5 $\mathrm{km}$ 沖合いから $5 \mathrm{~km}$ 沖合いまでは, 緩やかに減少し $10 \mathrm{~km}$ 打よ び $20 \mathrm{~km}$ 沖合いでは一定值を示した。全クロム $(\operatorname{Cr}(\mathrm{T}))$ に対す る懸濁物質に含まれるクロムの割合は，揖保川から播磨灘の沖合 いにいくにしたがって徐々に減少した。以上の結果は，皮革排水 に含まれる眯濁物質および河川水中で生成した懸濁物質の大部分 が，河川から海域へ輸送される間に沈降することを示唆してい

Table 2 Analytical results of dissloved chromium species and salinity in river and sea waters

\begin{tabular}{|c|c|c|c|c|c|c|}
\hline \multirow[b]{2}{*}{ Sampling stations } & \multicolumn{2}{|c|}{$\begin{array}{l}\operatorname{Cr}(\text { III }) \\
(\mu \mathrm{g} / l)\end{array}$} & \multirow[t]{2}{*}{$\begin{array}{l}\mathrm{Cr}(\mathrm{U}) \\
(\mu \mathrm{g} / l)\end{array}$} & \multirow[t]{2}{*}{$\begin{array}{c}\mathrm{Cr}(\mathrm{D})^{a)} \\
(\mu \mathrm{g} / l)\end{array}$} & \multirow[t]{2}{*}{ Org. $\mathrm{Cr}$ (III) $/ \mathrm{Cr}$ (D) } & \multirow[t]{2}{*}{$\begin{array}{c}\text { Salinity } \\
(\% 0)\end{array}$} \\
\hline & Inorg. & Org. & & & & \\
\hline R. Ibo $1^{b)}$ & 2.4 & 3.8 & $<0.01$ & 6.2 & 0.61 & 0.8 \\
\hline $2^{b)}$ & 1.3 & 1.8 & 0.3 & 3.4 & 0.53 & 3.4 \\
\hline Estuary & 1.5 & 2.4 & 0.1 & 4.0 & 0.60 & 14.1 \\
\hline $0.5 \mathrm{~km}$ offing from the estuary & 0.21 & 0.22 & 0.10 & 0.53 & 0.42 & 31.6 \\
\hline $2 \mathrm{~km}$ & 0.13 & 0.13 & 0.11 & 0.37 & 0.35 & 31.8 \\
\hline $3 \mathrm{~km}$ & 0.13 & 0.08 & 0.09 & 0.30 & 0.27 & 31.8 \\
\hline $5 \mathrm{~km}$ & 0.08 & 0.04 & 0.08 & 0.20 & 0.20 & 31.9 \\
\hline $10 \mathrm{~km}$ & 0.05 & 0.02 & 0.06 & 0.13 & 0.15 & 32.0 \\
\hline $20 \mathrm{~km}$ & 0.03 & 0.03 & 0.07 & 0.13 & 0.23 & 31.9 \\
\hline
\end{tabular}

a) $\mathrm{Cr}(\mathrm{D})$, total dissolved concentration of $\mathrm{Cr}$.

b) See footnote $b$ of Table 1 .

23）尾崎富生，吉村哲彦，奥野年秀，兵庫県公害研究所報告，17，83(1985). 
Table 3 Comparison of analytical results for surface waters

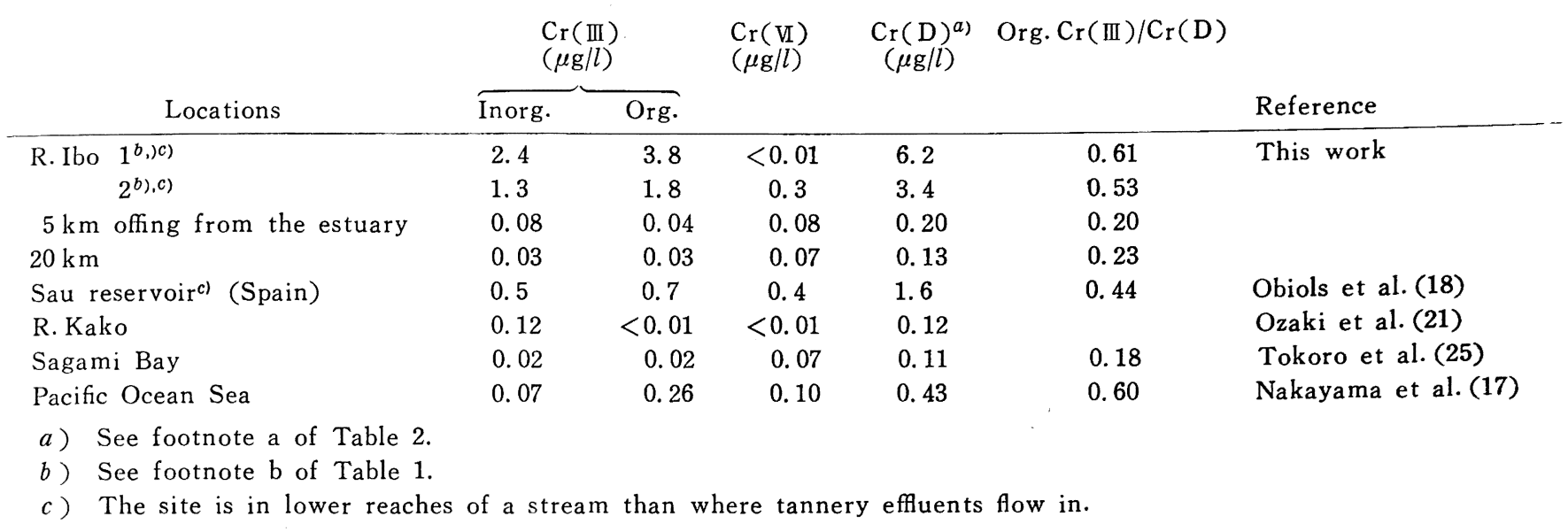

る。

\section{2 揖保川および播磨灘における溶存クロム}

揖保川および播磨灘における溶存クロムの分析結果を表 2 に示 す。汽水域における海水の混入割合の指標として塩分濃度も表 2 に示した。

表 2 に示したよらに, 海水中の $\operatorname{Cr}(\mathrm{V})$ は, $0.11 \sim 0.06 \mu \mathrm{g} / \mathrm{l}$ の 籁团でありほぼ一定值を示したが，河口から沖合いにいくにした がってわずかに減少する傾向がみられた。無機態 $\operatorname{Cr}($ III $)$ 抢よび 有機態 $\operatorname{Cr}($ III ) は揖保川上流から河口にいくにしたがって緩やか に減少し, 河口から $0.5 \mathrm{~km}$ 沖合いまでの間で急激に減少した。 また, $0.5 \mathrm{~km}$ 沖合いから $20 \mathrm{~km}$ 沖合いまでは, 緩やかに減少し た。溶存全クロム $(\mathrm{Cr}(\mathrm{D}))$ に対する有機態 $\operatorname{Cr}(\mathrm{II})$ の割合は河 川水中では 0.5〜0.6 であり河口から沖合いにいくにしたがって 娍少し, 沖合いでは約 0.2 を示した。

程分の測定結果は, 揖保川の地点 2 には海水が混入しているこ とを示した。また，河口では河川水と海水がいちじるしく混合し ていることを示した。さらに，河口から $0.5 \mathrm{~km}$ 沖合いの地点で は，河川水の影響はほとんど認められなかった。 以上の結果は, 河川水中のクロムが河口付近で海水に急激に拡
散し，希釈されることを示している。溶存クロムが懸濁物質に吸 着されたり，有機物質などと不溶性の錯体を生成し沈降すること も, 溶存ク口ム濃度の減少に寄与していると考えられる424。

\section{3 文献值との比較}

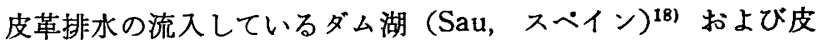
革排水の影響のない加古川 ${ }^{21)}$ ，相模湾 ${ }^{25)}$ おび太平洋の海水中 ${ }^{17}$ の溶存ク口ムの分析結果を表 3 に示す。表 3 に示したよらに，皮 革排水の影響を受けている揖保川とダム湖の淡水中の溶存クロム 濃度は, 皮革排水の流入していない加古川にくらべ高い値を示し た。また，溶存全クロムに対する有機態 $\operatorname{Cr}($ III ) の割合は，揖保 川とダム湖の淡水中では近い值を示した。播磨灘の海水中の無機 態 $\operatorname{Cr}(\mathrm{III})$ および $\operatorname{Cr}(\mathrm{V})$ の濃度は, 相模湾, 太平洋の值と同様 の值を示している。有機態 $\operatorname{Cr}(\mathrm{III})$ の濃度は, 相模湾の值とほぼ 一致しているが太平洋の值より低い値を示した。

（1988 年 4 月, 日本化学会第 56 春季年会において一部発表）

24) J. A. Campbell, P.A. Yeats, Estuar. Coast. Shelf Sci., 19, 513(1984).

25）所 裕之, 一色健司, 中山英一郎, 桑本 融, 日本海洋学 会要旨集, p. 182(1984). 


\title{
Distributions and Behavior of Chromium Species in Natural Waters - The Chemical Changes of Chromium Species in The Ibo River and Harima Nada-
}

\author{
Tomio Ozaki*, Tetsuhiko Yoshimura and Toshihide Oкuno \\ The Environmental Science Institute of Hyogo Prefectrure; \\ Yukihira-cho, Suma-ku, Kobe-shi 654 Japan
}

In order to understand the behavior of chromium at the confluence of the river and sea waters, the surface distributions of several chromium species have been investigated at the Ibo River with the influence of tannery effluents and Harima Nada (see Fig.1). The concentrations of particulate $\mathrm{Cr}$, dissolved inorganic $\mathrm{Cr}(\mathrm{III})$ and dissolved organic $\mathrm{Cr}(\mathrm{III})$ gradually decreased from the upper stream in the Ibo River to the estuary, rapidly decreased from the estuary to $0.5 \mathrm{~km}$ offing from the estuary and gradually decreased from $0.5 \mathrm{~km}$ to $20 \mathrm{~km}$ offing from the estuary. These results indicate that the chromium species in the river waters rapidly diffuse into and are diluted with the sea water near the estuary. The concentrations of $\mathrm{Cr}(\mathrm{V})$ in the sea waters at several sites fell within a narrow range $(0.06 \sim 0.11 \mu \mathrm{g} / l)$. 